The final version of this manuscript will appear in M. Lenz and A. Waldow (eds.), Contemporary

Perspectives on Early Modern Philosophy: Nature and Norms in Thought, Springer.

\title{
Intentionality Bifurcated: A Lesson from Early Modern Philosophy?
}

\author{
Lionel Shapiro, University of Connecticut
}

\begin{abstract}
This paper examines the pressures leading two very different Early Modern philosophers, Descartes and Locke, to invoke two ways in which thought is directed at objects. According to both philosophers, I argue, the same idea can simultaneously count as "of" two different objects - in two different senses of the phrase 'idea of'. One kind of intentional directedness is invoked in answering the question What is it to think that thusand-so? The other kind is invoked in answering the question What accounts for the success of our proper methods of inquiry? For Descartes as well as Locke, the two kinds of "ofness" come apart as a result of strong rationalist commitments. However, I will suggest that even if we reject such commitments, we go wrong if we assume that a single kind of intentional directedness suffices to address both questions.
\end{abstract}

\section{Introduction}

In the long history of philosophical reflection about intentionality-how thought is directed at the world - the seventeenth century is generally regarded as a heyday of innovation. The novelty has sometimes been exaggerated: scholars are increasingly emphasizing close connections between Early Modern theories of "ideas" and late Scholastic accounts of "concepts."1 In this paper, nevertheless, I will call attention to what I think is one genuinely new feature of some Early Modern theorizing about intentionality, a feature that has been overlooked. This is a pity, since it is a feature that goes missing in present-day theories, but deserves to be taken seriously.

According to the Scholastic tradition, cognition is (very roughly) a process in which the same forms that structure things in the world come to structure or "inform" our various cognitive capacities, starting with the sensory faculty and ending with the intellect. This theory is meant to accomplish two explanatory tasks at the same time. On the one hand, it is meant to address the question

(1) What accounts for our ability to entertain a thought that thus-and-so, and hence to make a judgment that is true or false depending on how things are?

On the other hand, the sharing of forms between things in the world and our cognitive capacities is meant to explain our successful use of these capacities. If we can understand how something's form comes to structure the intellect, this promises to let us understand how we might approach a

\footnotetext{
${ }^{1}$ See e.g. Perler 1996 and 2010, Pasnau 1997, Hoffman 2002, Brown 2007, Clemenson 2007, and Carriero 2009.
} 
grasp of that thing's nature. And such a grasp would count, in the highest degree, as successful use of our cognitive capacities. So the sharing of forms is also meant to address the question

(2) What accounts for the success of our proper methods of inquiry?

When Early Modern philosophers either jettison or radically reconstruct the Scholastic framework for understanding cognition, the possibility emerges that each of these explanatory tasks may require its own conceptual tools.

This paper will examine how two very different Early Modern thinkers, Descartes and Locke, find themselves needing to appeal to two different ways the same "idea" can be directed at an object. According to both philosophers, the same idea can be directed at two different objects. It can be the 'idea of' two different objects, in two different senses of the phrase.

One of these senses corresponds to the first of the above explanatory tasks: accounting for how we can make judgments that are true or false depending on how things are. Since this sense will be elucidated in terms of how ideas contribute to propositional mental acts, I will call it the propositional sense of 'idea of'. In addition to the propositional sense, which is common to Descartes and Locke, I will argue that each philosopher employs his own contrasting sense. These other senses correspond to the different ways Descartes and Locke approach the second explanatory task, that of accounting for cognitive success. But since both philosophers use the word 'represent' in this connection, I will speak in both cases of a representational sense of 'idea of' ${ }^{2}$ The structure of my interpretation is summarized in Table 1.

\begin{tabular}{lll}
\hline To account for & Descartes appeals to & Locke appeals to \\
\hline $\begin{array}{l}\text { truth-evaluable } \\
\text { propositional acts }\end{array}$ & propositional intentionality & propositional intentionality \\
$\begin{array}{l}\text { certain kinds of } \\
\text { cognitive success }\end{array}$ & $\begin{array}{l}\text { representational intentionality } \\
\text { (Cartesian version) }\end{array}$ & $\begin{array}{l}\text { representational intentionality } \\
\text { (Lockean version) }\end{array}$ \\
\hline
\end{tabular}

Table 1: Overview

For each philosopher, the twofold intentional directedness underwrites two kinds of normativity. On the one hand, Descartes and Locke share the traditional view that judgments are subject to a norm of truth, and we will see that what it takes for a judgment to achieve truth

\footnotetext{
2 I don't mean to claim that these are the only contexts in which Descartes or Locke use what we might regard as notions of representation. For general discussion of representation in Descartes and Locke respectively, see Simmons, forthcoming, and Lennon 2007.
} 
depends on the propositional intentionality of the ideas employed in the judgment. On the other hand, both philosophers hold that there are norms governing the improvement of ideas, the achievement of which will be explained in terms of their representational intentionality. For both philosophers, these representational norms will be a matter of how our ideas are beholden to mind-independent natures: Cartesian "true and immutable natures" or Lockean "real essences."

I have three aims in telling this story. First, I hope to show how my reading of Descartes and Locke resolves puzzles posed by their texts: in Descartes's case the notorious puzzle of "materially false ideas," in Locke's case the analogous but neglected puzzle of "inadequate ideas." (In each case, the puzzle is why what is alleged to be a deficient idea of some object doesn't count instead as an idea of another object.) Here I will draw on interpretations I have elaborated and defended in far greater detail elsewhere. ${ }^{3}$ Second, by pointing to the very different pressures that explain why each philosopher needs to appeal to two kinds of intentionality, I hope to illuminate their respective fundamental commitments concerning cognition. In each case, the need results from a characteristic rationalist commitment: in Locke's case the rationalism concerns question (1), while in Descartes's case it concerns question (2). Third, I will suggest that understanding why Descartes and Locke are driven to bifurcate intentionality should carry a lesson even for those present-day theorists who reject both rationalist commitments.

\section{Descartes}

My first task will be to explain the propositional sense of the phrase 'idea of', by exhibiting it as a familiar sense Descartes takes for granted when elucidating his talk of ideas. After that, I will present evidence that the propositional sense doesn't suffice for his explanatory purposes, and offer an account of the contrasting representational sense.

\subsection{Propositional ofness}

In a letter written to Mersenne as the Meditations awaited publication (AT 3:391-7, CSMK 3:184-74), Descartes stresses an ordinary, theoretically noncommittal sense in which a mental entity can count as an "idea of" something. He does so in response to an anonymous objector who claims to be puzzled by his talk of "the idea of God, the idea of the soul, and (in general) the

\footnotetext{
${ }^{3}$ Shapiro 2012 and 2010, respectively.

${ }^{4}$ References in this format will be to the edition of Adam and Tannery 1964-76 (henceforth AT), and to the translations in Cottingham et al. 1984-91 (CSM and CSMK). Where I have significantly modified a translation, the original is provided in brackets.
} 
ideas of imperceptible things" from which we receive no sensory images (AT 3:375-6).5 Granting that by 'idea' Descartes doesn't mean an image retained in the imagination, the objector asks for a "clearer explanation" of what he means by these phrases. Descartes protests:

Is it possible that [the objector] could not, as he says, understand what I mean by the idea of God, the idea of the soul, and the ideas of imperceptible things? I mean only what he must necessarily have understood himself when he wrote to you that he did not understand my meaning.

He goes on to explain:

For he does not say that he conceived nothing by [n'ait rien conceu par] the expressions 'God', 'soul', 'imperceptible things'; he just says that he did not know what was to be understood by the idea of these things. But if he conceived anything by these expressions, as he doubtless did, he knew at the same time what was to be understood by the ideas namely nothing other than the very thing [cela mesme] he conceived. (AT 3:392, CSMK 3:184, emphasis added)

The point here is a simple one. My idea of God, Descartes is saying, is whatever I conceive when I use the word 'God', and my idea of the soul is whatever I conceive when I use the word 'soul'. He then generalizes over all such examples:

[W]e cannot express anything by our words, when we understand what we are saying, without its being certain thereby that we have in us the idea of the thing which is signified by our words. (AT 3:393, CSMK 3:185, emphasis added; see also the Second Replies at AT 7:160, CSM 2:113)

If I conceive anything at all in using the word 'God', Descartes is saying, my mind has the idea of God. If I conceive anything at all in using the word 'soul', my mind has the idea of a soul. And so on. 6

When explaining what he means by an "idea of something," why does Descartes point to a relation between ideas and words? The answer is that his explanation in terms of words follows from a more fundamental principle that doesn't involve words. According to him, ideas serve to determine the overall "form" of "thoughts" (AT 7:160, CSM 2:113; AT 7:37, CSM 2:25-6). For

\footnotetext{
${ }^{5}$ Mori 2012 offers biographical, textual and philosophical evidence that the objector, whose letter Descartes received from Mersenne, was Hobbes.

${ }^{6}$ Cf. Perler 1996, 13-4.
} 
example, it is in virtue of the ideas it involves that one thought is a thought that God is a deceiver and another thought is a thought that souls are extended. I can now state the fundamental principle Descartes is relying on:

Proposition principle An idea of $x$ is an idea one can employ (as the relevant component of one's thought) in entertaining the thought that ...x...

For example, a person's idea of God is the one she employs when she entertains the thoughts that God is a deceiver, that she is not God, etc. This explains Descartes's next move in response to the objector: "how could he have said that God is infinite and incomprehensible ... unless he had an idea of him?" (see also AT 7:188, CSM 2:132; AT 9A:210, CSM 2:273)7

We can now understand why Descartes answers his critic by pointing to a connection between ideas and words. Suppose that I understand what I'm saying in using the words 'God is a deceiver'. Then I am entertaining the thought that God is a deceiver. According to the proposition principle, the idea that is the element of this thought corresponding to my word 'God' must be the idea of God. The principle also explains a connection between what an idea is "of" and the truth conditions for judgments that involve the idea. If one of your ideas is of God and a second idea is of infinity, you can employ them in an affirmation that is true just in case God is infinite.

Whenever an idea is "of" an object in the sense Descartes has explained, and which I have explicated using the proposition principle, let us say that the idea is of that object in the propositional sense. ${ }^{8}$ Martin Lenz calls attention to the importance of this sense for Early Modern theorists of ideas:

For many Early Modern authors, ideas are the components of beliefs that can be expressed using sentences. For example, if I have the belief that milk is white, I therefore also have at my disposal the ideas of milk and of white. ${ }^{9}$

\footnotetext{
${ }^{7}$ It may be objected that in the same letter Descartes rejects a distinction between two kinds of ideas, those "expressed by terms" and those expressed "by propositions" (AT 3:396, CSMK 3:186). For my purposes, however, it won't matter whether we talk about a thought that God is infinite or a thought of God as infinite, as long as this specification immediately determines a truth condition for a possible judgment. Cf. Perler 1996, 257-61 and Nuchelmans 1983, 42-4. For the dialectical context of Descartes's rejection of the above distinction, see Mori 2012.

${ }^{8}$ Elsewhere, I have argued that this sense is essential to understanding one strand of Descartes's epistemology: his view that we can delineate the natures of things by contemplation of what is contained in our clear and distinct ideas of them (Shapiro 2012, 396-8).

${ }^{9}$ Lenz 2010a, 254 (my translation).
} 
But the propositional sense of 'idea of' should also be familiar from present-day discussions of concepts. Consider, for example, Jerry Fodor's influential capital-letter notation. Where Early Modern theorists would speak of the 'idea of an animal', Fodor speaks of 'the concept ANIMAL'. He explains: "[C]oncepts are constituents of mental states. Thus, for example, believing that cats are animals is a paradigmatic mental state, and the concept ANIMAL is a constituent of the belief that cats are animals (and of the belief that animals sometimes bite, etc....)."10 Accordingly, the concept ANIMAL counts as being the concept of an animal in the propositional sense. Notice that neither Descartes nor Fodor needs to appeal to any relation of representation to elucidate what they mean by the idea of God or the concept ANIMAL.

\subsection{Why propositional ofness is not enough}

I will now argue that Descartes insists that what an idea is of in the propositional sense can diverge from what the same idea is of in some second sense, for which he uses the language of "representation." My evidence will come from his much-discussed reply to an objection by Arnauld concerning "material falsity." 11 Unlike most readers, ${ }^{12}$ I will take Descartes to be making a fundamental point about intentionality, rather than one specifically about sensory representation.

In the Third Meditation, Descartes's meditator makes a remark that puzzles Arnauld. He says that while there is a sense in which only judgments can be false, "there is a certain other falsity, a material kind, which occurs in ideas [quaedam alia falsitas materialis in ideis], when they represent non-things as things" (AT 7:43, CSM 2:30). For example, the meditator explains, "if it is true that cold is nothing but the privation [privatio] of heat, the idea which represents it to me as something real and positive deserves to be called false..." Arnauld interprets the meditator's scenario as follows.

Third Meditation scenario My idea of cold might turn out to represent something other than cold to me. In that case it would misrepresent its object, and therefore count as a false idea of cold.

\footnotetext{
${ }^{10}$ Fodor 1998, 6.

11 The extensive literature on Descartes and material falsity is examined in Shapiro 2012; see also De Rosa 2010 and Naaman-Zauderer 2010. My reading of Descartes's reply to Arnauld is most influenced by Margaret Wilson, who proposes that Descartes is distinguishing between two "senses of ... 'idea of'," namely a "presentational" and a "referential" sense (Wilson 1990, 69-70, 73-4). But neither of Wilson's two senses lines up with either of the two senses I attribute to Descartes (see Shapiro 2012, 401).

12 An exception is Wee 2006, 55-8.
} 
Arnauld then objects that this scenario is incoherent. According to him, an idea that represents something other than cold "is not the idea of cold" (AT 7:207, CSM 2:146). That is why, "if cold is merely a privation, there cannot be an idea of cold which represents it to me as a positive thing..." (AT 7: 206, CSM 2:145).

In his reply, Descartes insists that the Third Meditation scenario is coherent, as long as its words are understood as he had intended. ${ }^{13}$ Arnauld's points, he writes,

can be readily accepted if they are taken as he himself intends them [facile possunt admitti, prout ipse illa intelligit]. But I meant what I wrote in another sense [quae scripseram, alio sensu intellexi], which seems to me to be equally correct.

He will thus "dodge [Arnauld's] blows" by distinguishing senses of words. Let us see if we can identify the senses he has in mind. Recall the key premise of Arnauld's objection: an idea of cold is an idea that represents cold to the mind. This is how Descartes evaluates Arnauld's premise:

When [Arnauld] says 'if cold is merely a privation, there cannot be an idea of cold which represents it as a positive thing', it is clear that he is dealing solely with an idea taken in the formal sense... [W] hen we think of [ideas] as representing something we are taking them not materially but formally. (AT 7:232, CSM 2:162-3)

Here he is invoking common late Scholastic terminology, found in Suárez as well as the Coimbran commentators he studied at school. ${ }^{14}$ To take a concept or idea formally is to regard it insofar as it represents some object to the mind. Expressed using vocabulary Descartes uses interchangeably, it is to consider that object insofar as it "is objectively in the intellect." 15 Descartes concedes that Arnauld's premise is true if the term 'idea of cold' is taken in the "formal sense" Arnauld intends. By contrast, he says, Arnauld's premise is false if 'idea of cold' is taken in Descartes's own intended sense, which is apparently the above-mentioned "material" sense:

\footnotetext{
${ }^{13}$ For criticism of common readings according to which Descartes agrees with Arnauld that the scenario is incoherent, and denies that it is what he had in mind in the Third Meditation, see Shapiro 2012, 391-3.

${ }^{14}$ Suárez (1597/1960-6, 8.3.16/2:106) is cited by Wells (1984, 32n36). For similar passages from Pedro da Fonseca and Antonio Rubio, see Clemenson 2007, 43-5.

${ }^{15}$ More precisely, I claim that Descartes uses the two locutions interchangeably when discussing the intentional directedness of ideas. I take no position on the contested ontology of objective being in Descartes: i.e. whether or not the act of the intellect that represents some object is really distinct from the object insofar as it is objectively in the intellect, what Descartes elsewhere call an idea "taken objectively" (AT 7:8, CSM 2:7). See e.g. Ayers 1998, 10678 .
} 
[I]f cold is simply a privation, the idea of cold [taken materially] is not cold itself insofar as it is objectively in the intellect [that is to say, it does not represent cold], but something else, ... namely a sensation which has no existence outside the intellect. (AT 7:233, CSM 2:163)

Taken in the material sense, the idea is still of cold (here supposed to be a privation), even though what the idea represents to the mind is a mere sensation. ${ }^{16}$ Hence the Third Meditation scenario, interpreted as Descartes had intended, is perfectly coherent.

But what is Descartes's intended "material" sense, such that whether an idea is "of cold" in this sense doesn't depend on its representing cold to the mind? I will now argue that the material sense is simply the propositional sense. That is because this reading makes best sense of how he explains the consequences of taking the idea of cold materially:

[If] we were taking them materially, [ideas] would have no regard to [nullo modo ... respicerent] the truth or falsity of their objects ... Thus, whether cold is a positive thing or a privation, I do not on that account have a different idea of it [taken materially, that is], but there remains in me the same one I have always had [non aliam idcirco de ipso habeo ideam, sed manet in me eadem illa quam semper habui] (AT 7:232, CSM 2:163).

His point seems to be this. Which of my ideas counts as an idea of cold in the propositional sense doesn't depend on whether cold turns out to be something metaphysically "true" or "false" - a real quality or an unreal privation. By contrast, which of my ideas counts as representing cold to my mind does depend on what cold turns out to be. If cold is a positive being, a "different idea" of mine will count as being "of cold" in the formal sense than if cold is a privation. So, depending on what cold turns out to be, I have a "different idea of it" in the formal sense. But whether cold is a positive being or a privation, I certainly have "the same idea of it" in the propositional sense. This is the idea I express by 'cold', the idea I use when I wonder, e.g., whether cold might be a privation. Taken in the propositional sense, it can't turn out that this idea isn't really "of cold"!

We have now found Descartes's explanation of why the Third Meditation scenario is coherent. The idea of mine that is guaranteed to be of cold in the "material" or propositional sense might turn out to be an idea of something else in the "formal sense."

\footnotetext{
${ }^{16}$ I defend this identification of what the idea in Descartes's example represents in Shapiro 2012, 389-90. For a contrary position, see De Rosa 2010, 55, 69-79.
} 


\subsection{Representational ofness}

Where Descartes speaks of the idea of an object in the "formal sense," let me speak of an idea of that object in the representational sense. So far, I have said nothing to explain this sense, but have merely argued that Descartes distinguishes representational from propositional ofness. To understand the role that representational ofness plays in Descartes's thought, it will be useful to have a few examples.

The Third Meditation scenario under discussion between Descartes and Arnauld is purely hypothetical: there is reason to think Descartes doesn't regard cold as a privation. ${ }^{17}$ But he says that the same predicament as in his hypothetical case "often happens in the case of obscure and confused ideas..." (AT 7:233, CSM 2:163). What actual examples, then, might he have in mind of ideas that are propositionally of something they fail to be representationally of? Consider first the confused idea a non-philosopher expresses by the word 'cold'. ${ }^{18}$ Perhaps this idea is propositionally of a quality in bodies, a quality the vulgar call 'cold', one that from the standpoint of Descartes's science has turned out to be a certain state of motion. Yet, as I have interpreted the Fourth Replies, the same idea is representationally of another object, namely a sensation which exists only in the mind. The non-philosopher may confuse this sensation with the object the idea is propositionally of, namely (we are supposing) the state of motion she calls 'cold'. This would explain why she is liable to form a false judgment as to the latter quality's nature. 19

Second, there is the Third Meditation's example of the ordinary "idea of the sun" which seems to be "acquired from the senses" (AT 7:39, CSM 2:27). This is an example used by the Coimbran commentators, who argue that the perception represents a small disk, not the sun. ${ }^{20} \mathrm{I}$ believe there is reason to hold that Descartes is agreeing with them that this idea represents a small disk, rather than the sun. ${ }^{21}$ Still, on his view, it remains an idea of the sun in the propositional sense. It is the idea a peasant uses in forming the false judgment that the sun is

\footnotetext{
${ }^{17}$ Hoffman 1996 and Nelson 1996.

${ }^{18}$ For a recent discussion that includes a survey of the literature on Cartesian sensory ideas, see De Rosa 2010.

${ }^{19}$ Compare Descartes's description of the hypothetical materially false idea: "the obscurity of the idea gives me occasion to judge that this idea of the sensation of cold represents some object called 'cold' which is located outside me" (AT 7:234-5, CSM 2:164). Though the idea is in fact representationally of a sensation, I may take it to be representationally of its propositional object, namely the quality I called 'cold'. Even if this mistake doesn't amount to an explicit judgment (one only a philosopher could make!), it can account for my false judgment about that quality.

${ }^{20}$ In Doyle 2001, 162-3 and 172-3; see also Wells 2003, 27-30.

${ }^{21}$ Here I agree with Clemenson 2007, 71. See also Grüne 2010, 34-5n38, who sees this consequence of her reading as a difficulty.
} 
smaller than the earth. Indeed, what accounts for this false judgment is that the peasant confuses the two objects the idea is "of" in the two senses.

A third likely example comes from a letter written in 1645 :

When the ancients named [nommoient] many gods they did not mean many all-powerful gods, but only many very powerful gods, above whom they imagined a single Jupiter as sovereign; and consequently, to this Jupiter alone the applied the idea of the true God, this idea being presented to them in a confused manner. (AT 4:188, CSMK 3:248)

Here Descartes appears to be saying that the idea a pagan priest expressed by 'Iuppiter' is in one sense an idea of the true God. ${ }^{22}$ Clearly, however, the pagan's idea is propositionally of Jupiter. When the pagan asserts the Latin equivalent of 'Jupiter is subject to the fates' (cf. AT 1:145, CSMK 3:23), he is asserting that Jupiter is subject to the fates, not that the true God is subject to the fates. The pagan confuses the true God his idea represents with the mythological object the idea is propositionally of.

\begin{tabular}{lll}
\hline & is propositionally of & is representationally of \\
\hline $\begin{array}{l}\text { idea the vulgar express } \\
\text { by 'cold' }\end{array}$ & $\begin{array}{l}\text { a quality in bodies (which turns } \\
\text { out to be a state of motion) }\end{array}$ & a sensation in the mind \\
$\begin{array}{l}\text { ordinary sensory idea } \\
\text { expressed by 'the sun' }\end{array}$ & the sun & a small disk \\
$\begin{array}{l}\text { idea a pagan priest } \\
\text { expressed by 'Iuppiter' }\end{array}$ & Jupiter & the true God \\
\hline
\end{tabular}

Table 2: Cases where propositional and representational ofness may diverge

These potential examples, summarized in Table 2, may help us answer the most pressing question: Why does Descartes appeal to representational ofness in addition to propositional ofness? My proposal is that the role of representational ofness needs to be understood in terms of Descartes's theory of clear and distinct ideas. On one attractive reading, a clear and distinct idea is an idea that perspicuously reveals the nature of the object it is an "idea of" in the propositional sense. For example, a clear and distinct idea of body is an idea that enables one to judge with certainty that body is extended substance. ${ }^{23}$ According to Descartes, rational reflection of the

\footnotetext{
22 See Wee 2006, 56-7.

23 For similar readings of clarity and distinctness see Alanen 2003, 159 and Clemenson 2007, 72-5.
} 
sort exemplified by the Meditations allows us to progress from obscure or confused ideas to clear and distinct ideas. What object is the resulting idea propositionally of, what object's nature does it perspicuously reveal? I propose that this is the very object the original idea already represented to the mind.

Reflective improvement of ideas If IDEAI is representationally of $x$, then there is a process of rational reflection that takes the mind from IDEA1 to some IDEA2 that (i) is propositionally of $x$, and (ii) counts as clear and distinct in the sense that it perspicuously reveals the nature of $x$.

Take, for example, the confused idea our pagan priest expresses by 'Iuppiter' (see Table 3). While this idea is propositionally of Jupiter, it is representationally of the true God. This status explains how the pagan is capable of reflectively refining the idea to yield a clear and distinct idea that is propositionally of the true God, and perspicuously reveals his nature. And this is the sense in which "the idea of God is imprinted on the human mind in such a way that everyone has within himself the power to know him" (AT 4:187, CSMK 3:248).

It is this kind of presence of an object to the mind that representational ofness consists in: a kind of presence for which Descartes is happy to borrow the Scholastic terminology of "objective being in the intellect." My thesis so far has been that this kind of Cartesian intentionality, a kind responsible for our ability to achieve clear and distinct understanding of "true and immutable natures," needs to be distinguished from the kind I have called propositional, the kind responsible for a judgment's truth conditions.

\begin{tabular}{lll}
\hline & is propositionally of & is representationally of \\
\hline $\begin{array}{l}\text { IDEA1 (confused idea a pagan } \\
\text { priest expresses by 'Iuppiter') }\end{array}$ & Jupiter & the true God \\
$\begin{array}{l}\text { IDEA2 (clear and distinct idea } \\
\text { resulting from reflection) }\end{array}$ & the true God & the true God \\
\hline
\end{tabular}

Table 3: A case of Cartesian idea-improvement

\section{Locke}

I will now argue that Locke too finds himself needing to invoke a kind of ofness that contrasts with propositional ofness. ${ }^{24}$ One place in the Essay where he does so is when discussing our

\footnotetext{
${ }^{24}$ See Lenz 2010b, 345ff and 2010a, 271-2 for a related attribution to Locke of two dimensions of content, which likewise stresses the role of Locke's ideas in mental propositions.
} 
complex ideas of the species of substances. These are the ideas expressed by words like 'water', 'gold', 'dog', 'man', etc. My proposal is that what Locke explains in terms of the doctrine of the "nominal" and "real essences" of substance species can be illuminated in terms, respectively, of the propositional and representational intentionality of substance ideas. ${ }^{25}$

\subsection{Propositional ofness}

Let me first use an example to illustrate Locke's appeal to propositional ofness when discussing substance-ideas. Locke quotes from a recently published collection of anecdotes:

When the Abbot of St. Martin was born, ... he had so little the Figure of a Man, that it bespake him rather a Monster. 'Twas for some time under Deliberation, whether he should be baptized or no. However, he was baptized and declared a Man provisionally.... $\left(3.6 .26: 454^{26}\right)$

Suppose we wish to determine whether this oddly-shaped fellow is a man, i.e. whether he deserves to be "ranked" into the human species - or, in Locke's preferred linguistic formulation, whether he has a "right to the name Man" and thus has the "nominal essence" of this sort or species (3.3.12:414-5, 3.3.18:419). ${ }^{27}$ What we're really interested in when we ask this question is the truth of a "mental proposition," namely the proposition that an animal with such-and-such features and capabilities is a man. According to Locke's theory of "mental propositions," this proposition is formed by "joining" two ideas (4.5.2:574, 4.5.5:575-6). ${ }^{28}$ What are these two ideas “of"? As long as 'idea of' is used in the propositional sense, there is an immediate answer: the first is the idea of such-and-such an animal, and the second is the idea of a man. Finally, the proposition will be true provided these two ideas "agree" with each other with respect to "necessary connexion" in the same subject (4.1.3:525, 4.7.5:594). And that requires that

\footnotetext{
${ }^{25}$ In Shapiro 1999, 587-90, I proposed that Locke's distinction between the nominal and real essences of substance kinds coincides with a distinction between kinds of content (cf. Prinz 2000). Here, I follow Shapiro 2010 in explaining that distinction in terms of propositional and representational intentionality.

${ }^{26}$ References in this format will be to Locke's Essay (by book, chapter, section, and page number in Locke 1975).

27 Though Locke insists that his usage of 'species' and 'sort' is a mere matter of Latin versus English (3.3.12:414, 3.5.9:434), 'species' typically expresses a contrast with 'genus' less often expressed by 'sort' (e.g. not at 3.3.15:417, 3.6.1:439). Locke's English for 'genus' is 'kind' (2.32.6:386, 3.1.6:404), though this term too is often used without any intended contrast $(2.32 .24: 393,4.6 .4: 580)$. Here I will use 'species' as the Lockean term.

${ }^{28}$ Perler 1996, 261n notes that Locke's theory of mental proposition has no counterpart in Descartes. This difference needn't prevent us from isolating a common notion of propositional ofness in both philosophers: see note 7 above.
} 
whatever "conforms to" the idea of such-and-such an animal necessarily also "conforms to" the idea of a man. ${ }^{29}$

Summarizing, we can say that what it takes for something to belong to the species man is for it to conform to an idea that is "of a man" in the propositional sense, such as the idea I express by 'man' (3.3.12:414-5, 3.6.7:443). Suppose now that my idea is the one Locke says people "commonly" express by that word, namely the idea of "a Body of the ordinary shape, with Sense, voluntary Motion, and Reason join'd to it" (4.6.15:589-90). Then I can say that being a man is a matter of being a body of the ordinary shape with sense, voluntary motion and reason joined to it. In short, by contemplating the composition of a complex idea of mine that countsin the propositional sense-as an idea of man, I can come to know necessary and sufficient conditions for being a man. This will be important in Sect. 4.

\subsection{Why propositional ofness is not enough}

I am now ready to argue that Locke also appeals to a second, non-propositional sense in which an idea can be "of" a species of substance. Switching from man to Locke's other favorite species, suppose that the complex idea we express by the word 'gold' is composed out of ideas of yellowness, a certain density, malleability, fusibility, solidity, and extension, together with the idea of their union "in an unknown substratum" (cf. 2.24.37:317, 2.32.23:392 and 3.6.2:439). Call this complex idea IDEA1. Locke stresses that IDEAI fails to be "a perfect complete Idea, of a sort of things" (2.32.23:392). For it omits, among other features, fixedness (non-volatility), which has been observed to coexist with the features already included. And he urges natural historians to "rectify" this imperfection:

[W] ... must enquire into the Nature and Properties of the Things themselves, and thereby perfect, as much as we can, our Ideas of their distinct Species ... [W] must, by acquainting ourselves with the History of that sort of Things, rectify and settle our complex Idea, belonging to each specifick name. (3.11.24:520-1; see also 3.11.25:521-2)

Suppose, in what follows, that we have followed Locke's advice and added the idea of fixedness to $I D E A 1$, and that we now use our word 'gold' to express the resulting "perfected" idea IDEA2.

\footnotetext{
${ }^{29}$ Ott 2012 stresses the connection between the truth of a Lockean mental proposition (the agreement of its component ideas) and what the ideas in the proposition are of: "whether ideas agree or disagree is a function of ... what they are ideas of" (1087). Though Ott's discussion concerns simple ideas, his "of-ness" thus plays the role of what I am calling propositional ofness.
} 
We can now formulate a puzzle modeled on Arnauld's puzzle for Descartes. As we will soon see, Locke repeatedly makes two claims that appear to be inconsistent:

(a) IDEA1 and IDEA2 are ideas of distinct species.

(b) IDEA2 is a more perfect idea of the same species of which IDEAI was an idea.

Notice the parallel with Arnauld's charge that Descartes is committed to the claim that a given idea might simultaneously be a "materially false idea of cold" and an idea of something other than cold. Unlike Arnauld's puzzle, this puzzle hasn't received attention; indeed, Locke's claim (b) has been overlooked. Several readers have tried to explain what he means when he speaks of more or less perfect substance ideas. ${ }^{30}$ What hasn't been appreciated is that he speaks of more or less perfect ideas of the same species of substance.

Once again, the contradiction would disappear if we concluded that 'of' is used in different senses in (a) and (b). This already gives us reason to suspect that Locke may be working with two kinds of intentionality. The key to distinguishing and identifying them is to notice that claims (a) and (b) occur in entirely different contexts in the Essay. The places where Locke endorses claim (a) are all contexts where he is concerned with explaining what counts as gold, silver, a man, etc. Since "each abstract Idea, with a name to it, makes a distinct Species," he argues, the "sorting of Things is the Workmanship of Men" (3.6.37-8:462-3; also 3.5.7:432, 3.3.14:416-17). As explained above, whether some object counts as gold depends for Locke on whether the object conforms to the idea of gold in the propositional sense. So 'idea of' in claim (a) expresses propositional ofness. This lets us fill in our first column in Table 4. After all, the idea I now express by 'gold' is, in the propositional sense, an idea of gold. According to Locke's claim (a), then, the idea I formerly expressed by the word 'gold' must have been an idea of a distinct species, one that doesn't require fixedness.

By contrast, Locke endorses claim (b) in contexts where he isn't focusing on the role of our ideas in determining what counts as gold, silver, a man, etc. Instead, when he stresses that we "have different Ideas of the same Substance" (3.9.13:482-3), he is explaining that our complex ideas are "imperfect and inadequate" as "representations" of the species of substances found in nature $(2.31 .6: 378,2.31 .11: 382,2.31 .13: 383) .{ }^{31}$ As we have seen, he concludes from this that

\footnotetext{
30 See esp. Ayers 1991, vol. 2: 75-7, Mattern 1986, and Atherton 2007.

31 There is an explicit cross-reference from the opening sentence of 3.9.12:482 to the opening sentence of 2.31.6:378. In both places, Locke contrasts the inadequacy he has in mind with a second inadequacy: substance ideas also count as inadequate when (inappropriately) regarded as revealing the "real essences" of species.
} 
"we must ... perfect, as much as we can, our Ideas of their distinct Species." Yet he concedes that our ideas will never be "exact Representations" of these species (3.9.20:488; also 3.9.17:486, 2.31.8-10:380-2, 2.32.24:392-3, 4.3.26:556-7). In other words, IDEA1 and IDEA2 are more or less imperfect representations of the same species of substance. ${ }^{32}$ Let us refer to the species in question, the one mentioned in claim (b), as $G$. Locke himself, well aware that he can't identify this species as gold, picks out $G$ using descriptions such as "that sort of Substance, we denote by the word Gold" (2.31.9-10:381-2) or "that sort of Body the Ring on his Finger is made of" $(3.9 .17: 486){ }^{33}$

In short, I have argued that according to Locke, an idea that is "of gold" in the propositional sense will also count as an idea "of" some other species in a sense relevant to representation.

\begin{tabular}{lll} 
& is propositionally of & is representationally of \\
\hline $\begin{array}{l}\text { IDEA1 (idea I formerly } \\
\text { expressed by 'gold') }\end{array}$ & $\begin{array}{l}\text { a species distinct from gold } \\
\text { (doesn't require fixedness) }\end{array}$ & [same as below] \\
$\begin{array}{l}\text { IDEA2 (perfected idea I } \\
\text { now express by 'gold') }\end{array}$ & the species gold & $\begin{array}{l}\text { call this species } G \\
\text { (it is distinct from gold) }\end{array}$ \\
\hline
\end{tabular}

Table 4: A case of Lockean idea-improvement

\subsection{Representational ofness}

To understand how IDEAI and IDEA2 count as representing the same species $G$, we must turn to the three chapters of the Essay (2.30-32) devoted to ideas taken "in reference to things ... which they may be supposed to represent." Here Locke's central question is this: To what extent do our various ideas "have a Conformity ... with their Archetypes"? By 'archetype' he means a model to which something else is intended to conform. And he argues that two kinds of ideas, simple ideas and complex ideas of substances, are appropriately intended to conform to archetypes outside the mind. He stresses that the relevant "conformity" between idea and object isn't the

\footnotetext{
${ }^{32}$ In several of these passages, Locke doesn't expressly note that he is talking about species rather than individuals. Yet taken together, and in their contexts, they demand the former construal. In once instance, Locke clarifies his intention in the Essay's fourth edition. Rather than speak of that person who "has the perfectest Idea of any particular Substance" he now speaks of that person who "has the perfectest Idea of any of the particular sorts of Substance" (2.23.7:299).

33 In two striking passages (analyzed in Shapiro 1999, 561-4), Locke complains of how "hard it is" to specify the species of which IDEA1 and IDEA2 are imperfect ideas without "cross[ing his] purpose" by using the word 'gold" rather than just mentioning it (3.6.19:449, 3.6.43:465-6).
} 
literal "sharing of form" appealed to by the Scholastic tradition. Rather, it is merely a "steady correspondence" (2.30.2:373): what we would today call a correlation.

Locke's account of representation as conformity to an appropriate archetype is spelled out most explicitly for simple ideas. ${ }^{34}$ But there is every reason to think the general account is supposed to apply to complex ideas of substances as well. Here conformity by correlation needs to be understood as follows.

Conformity by correlation Suppose I have a complex idea (propositionally) of a substance with features $F_{1}, F_{2}, \ldots F_{n}$. My idea conforms by correlation to a species $S$ to the extent that having features $F_{1}, F_{2}, \ldots F_{n}$ correlates with belonging to species $S$, and can thus serve to distinguish things of that species. (For sets of qualities serving as "marks" used to "distinguish" substance species, see 2.23.8:300 and 4.6.11:585.)

I can now say what I think it means for an idea to be "of" a species of substance in Locke's representational sense.

Representation ofness and adequacy My complex idea is representationally of a substance species $S$ provided I appropriately intend that the idea conform by correlation to $S$. And such an idea will adequately represent the species $S$ to the extent that it does conform by correlation to $S$. This account of representation explains what Locke means when he approves of those natural historians who intend their substance ideas to be "Representations in the Mind, of Things that do exist, by Ideas of those qualities that are discoverable in them" (2.31.6:378, 2.31.8:380-1, 3.9.13:482). And it explains why he says, concerning our "specific Ideas of Substances," that we should "endeavour ... to make them as complete as we can, whereby I mean, that we should put together as many simple Ideas, as being constantly observed to co-exist, may perfectly determine the Species" (4.12.14:648).

But what is the species $G$ such that I appropriately intend that the combination of features singled out by the idea I express by 'gold' should correlate with membership in $G$ ? To answer

\footnotetext{
${ }^{34}$ In Shapiro 2010, I argue that the representational ofness of simple ideas diverges from their propositional ofness. For a similar view, see Ott 2012 (1089-93). Ott reserves the label "representation in the strict sense-the ofness of an idea" for a notion that plays the propositional role ( $\$ 4$, see note 29 above). He distinguishes this "of-ness" of ideas from their "role as marks or signs" that corresponds roughly to what I call Locke's representational ofness. Since Ott and I recognize that Locke uses 'represent' in both ways (Shapiro 2010, 579n23), this difference is chiefly terminological. There remain two substantive differences. First, Ott's Locke regards color-ideas, unlike shape-ideas, as "blank effects" lacking the "of-ness" that corresponds to my propositional ofness. On my reading, by contrast, color- and shape-ideas each possess both kinds of intentionality. Second, unlike Ott, I argue that Locke takes shapeideas to be perfect "marks or signs" of powers to produce ideas (Shapiro 2010, 561). Locke doesn't, implausibly, take these ideas to be perfect marks or signs of the very shapes they are propositionally of.
} 
the question, consider our purpose in employing substance ideas. Here is Locke's explanation of our purposes in forming all "abstract complex Ideas":

[T]he first Thing [the mind] does, as the Foundation of the easier enlarging its Knowledge, ... of the things themselves, that it would know ..., is to bind them into Bundles, and rank them so into sorts, that what Knowledge it gets of any of them, it may thereby with assurance extend to all of that sort.... (2.32.6:386, emphasis added)

In the case of substance ideas, this goal will amount to inductive projectibility. When I discover that a particular piece of gold was dissolved by aqua regia, Locke holds, I can with fair "assurance" predict that other pieces will likewise be dissolved.35 (For his interest in induction, see 4.3.29:560, 3.6.24:452, 4.6.13:588, and 4.12.10:645.) It is our concern for inductive projectibility, then, that underwrites Locke's injunction that we should perfect our ideas of substance species so as to make them better represent their archetypes. Calling attention to two of the claims cited above, Richard Boyd remarks: "Officially in these passages Locke is addressing the problem of the 'inadequacy' of kinds [that is: ideas of kinds] of substances rather than the problem of inductive categories, but ... I am inclined to think that he means the solution to apply to the latter problem as well.,"36

Boyd's suggestion, which is bolstered by the displayed passage, lets us explain how a species $G$ is picked out as the one represented by the idea I express by 'gold'. The key is that there is reason to attribute to Locke the following claim about what grounds inductive projectibility.

Projectibility and explanatory constitutions A substance idea is inductively projectible to the extent that it conforms by correlation to a species whose members share a common "internal constitution," one that explains their possession of the features already included in the idea, as well as those additional features one will come to include if one continues to perfect the idea (by including features that have hitherto been "constantly observed to co-exist" with the set already included).

As Locke says, such a shared "real constitution ... is the foundation of all those Properties, that are combined in, and are constantly found to co-exist with the nominal Essence" (3.6.6:442).

\footnotetext{
35 This claim would require serious qualification to be defensible. However, here is all Locke need be committed to: the more we "perfect" a substance idea, the more we may expect that there will be reliable generalizations concerning "coexistence" of the features collected in the idea with additional ones, and this expectation is relevant to induction.

${ }^{36}$ Boyd 1991, 131-2. If this is right, Locke's position resembles Boyd's own conception of "natural kinds" (1999; 2010), as well as that of Millikan 2000.
} 
According to the Scholastic metaphysical framework he adapts to his purposes, this internal constitution serves as the "real essence" of the species in question, the source from which "flow" the "endless" additional essential "properties" or propria of the species (2.32.24:392-3, 2.31.10:382, 3.11.22:520, 4.6.11:585). ${ }^{37}$

In short, Locke is saying that I appropriately intend that the complex idea I express by 'gold' should conform by correlation to the species $G$ that is picked out by possession of this underlying constitution. This means that my idea is representationally of the species with the explanatory internal constitution. Yet my current idea is highly unlikely to perfectly represent that species. There will be things that agree to my idea, and hence belong to the species my idea is propositionally of (namely the species gold), but don't belong to the species my idea is representationally of.

This imperfect representation accounts for failures of induction. Locke recounts the "sad Experience" made by chymists "when they, sometimes in vain, seek for the same Qualities in one parcel of Sulphur, Antimony, or Vitriol, which they have found in others" (3.6.8:443). Though the chymists intend their substance ideas to conform to sorts with explanatory internal constitutions, their ideas end up doing so only imperfectly. Their ideas fail to be "exact representations" of the archetypes they are intended to conform to, and thus stand in need of perfecting. As Peter Anstey has recently observed, in the course of a reading that in many respects matches the one I have summarized here and elaborated elsewhere, Locke is a "convergent conventionalist" about our ideas of substance species. 38

\footnotetext{
${ }^{37}$ On Locke's use of 'property' to mean proprium in the sense derived from Porphyry, see e.g. Ayers 1991, vol. 2 , 21, 67-74 and Pasnau 2011, 658-60. Contrary to Pasnau, I am arguing that Locke's embrace of natural kinds in the Essay does "depend on the notion of an explanatory essence" from which a species' observable properties flow.

38 Anstey 2011, ch. 11; cf. the section "Converging on a real essence" in Shapiro 1999, 576-82. Kornblith 1993, ch. 2 sketches a similar account of Locke's implicit view of "chemical method," but claims it contradicts Locke's "official position." Several interpreters besides Anstey and myself have argued that Locke officially embraces natural kinds. However, their conceptions differ from the one I intend. According to Conn 2002, what is required for there to be natural kinds is that (a) each set of perceptible features corresponds to some shared internal constitution. As I read Locke, he denies (a). Instead, he holds there to be natural kinds in the sense that (b) some ways of sorting objects by their perceptible features count as more natural than others, by coming closer to corresponding to a shared internal constitution. Though Stuart 1999, 285-91 discusses Boyd and Kornblith, I read him as attributing to Locke a qualified version of (a), not (b). On the other hand, Pasnau 2011, 642-7 attributes an embrace of natural kinds in a very strong sense, for which I find no evidence in the Essay: "there is a unique system of species (and higher genera) that best captures the similarities and differences among individuals." For an analysis of Locke's carefully reasoned ambivalence about whether there are any "prefixed Bounds" of species, any boundaries "made by Nature" (3.6.30:457-8, 3.6.43:466), see Shapiro 1999, 582-7.
} 


\section{Cartesian and Lockean rationalism}

We have now seen both Descartes and Locke make use of a distinction between two kinds of intentionality, each of which is appealed to in explaining or describing a different aspect of our mental lives. One kind, which both philosophers address using Scholastic metaphysical frameworks, is appealed to when answering question (2) of my Introduction: What accounts for the success of our proper methods of inquiry? In Descartes's case, the method in question is that of attaining, through rational reflection, clear and distinct ideas that perspicuously reveal fundamental natures. In Locke's case, the method in question is inductive inference, success at which requires that our substance ideas conform by correlation to sorts picked out by explanatory real essences. Each philosopher finds that the kind of intentionality he invokes in answer to question (2) isn't straightforwardly relevant to question (1): What accounts for our ability to think that such-and-so, and hence to think of something in the propositional sense? Let us now compare the respective reasons why Descartes and Locke require different kinds of intentionality to answer the two questions.

The driving force behind Locke's divorce between propositional and representational ofness is his approach to question (1). Here he advocates a rationalist thesis.

Lockean rationalism Reflection on what is required for thinking of gold or of a man (in the propositional sense) reveals informative necessary and sufficient conditions for something to count as gold or count as a man. 39

This rationalism is tied to Locke's preoccupation with the possibility of clarifying and resolving apparent disagreements, such as the one concerning the abbot of St. Martin. Once you convey to me the simple components of the idea you express by 'man', we can agree on informative truth conditions for the propositions you express using that word (cf. 3.9.16:484-5, 3.11.7:511-12). Yet, quite reasonably, Locke concedes that the results of such reflection have no obvious bearing on the question of what structures in the world our successful use of such thoughts depends on.

But Descartes's example shows that a divorce between propositional and representational ofness needn't have this motivation. Unlike Locke, Descartes has remarkably little to say about question (1). There is no Cartesian theory of propositional intentionality. In Descartes's case, rather, the divorce is driven by his approach to question (2). This is where he, in turn, advocates a rationalist thesis.

\footnotetext{
${ }^{39}$ A parallel claim hold for ideas of modes, such as the ideas of a triangle and of injustice.
} 
Cartesian rationalism Reflection on our ideas can yield an understanding of fundamental natures, of what makes something what it is. ${ }^{40}$

Yet, quite reasonably, Descartes concedes that the natures he takes to be revealed through rational reflection on our ideas may have little to do with the objects we are currently thinking of, in the propositional sense. Rational reflection on the idea the pagan priest expresses by 'Iuppiter' can yield an understanding of the nature of the true god, not of the chimerical non-thing his idea is propositionally of. Likewise, reflection on the confused sensory idea the non-philosopher expresses by 'cold' can reveal the nature of a sensation, not the physical quality this idea may be propositionally of. And no amount of reflection on the idea the peasant expresses by 'sun' can reveal the nature of the sun.

The fact that Locke's and Descartes's bifurcations of intentionality are driven by different rationalist commitments explains an important difference between them concerning the ways in which it can make sense to seek an improved idea of the same object. According to Descartes, one idea can be better than another in that it more perspicuously reveals a nature. Given that some confused ideas can have two different objects, this results in two very different kinds of cases in which two ideas count as better and worse ideas of the same object. On the one hand, there are cases where the better idea represents the same object as the worse idea, even though it counts as the idea of a new object in the propositional sense. Such a case is displayed in Table 3. Once our pagan makes his idea clear and distinct, it no longer counts, in the propositional sense, as an idea of Jupiter. On the other hand, there are also cases where the better idea remains an idea of the same object in the propositional sense, even though it may represent a new object. In order to go from believing that the sun is smaller than the earth to understanding that it is "several times larger than the earth" (AT 7:39, CSM 2:27), I must come to employ a radically new "idea of the sun" (in the propositional sense). Above, I suggested that these two ideas have distinct representational objects. In any case, it is evident that for Descartes the ends of inquiry can be furthered by replacing a confused idea with a clear and distinct one that remains (in the propositional sense) an idea of the same object.

\footnotetext{
${ }^{40}$ Locke agrees with this claim in the case of simple ideas and ideas of modes. Here the idea serves not just as nominal essence of a species, but also as its real essence (3.3.18:418, 3.4.3:421, 3.5.14:436). To learn what makes an action an injustice or makes a body crimson, it suffices to inspect the respective ideas (provided, in the latter case, that one has learned the general lessons of chapter 2.8 about color-ideas). Of course, such inspection is a far cry from the serious intellectual work Descartes envisions.
} 
That is not so for Locke. By his lights, a better idea can't be one that more perspicuously reveals an explanatory nature. In this regard, all substance ideas are equally deficient - while all simple ideas and ideas of modes are equally flawless. ${ }^{41}$ According to Lockean rationalism, the idea of each substance species (in the propositional sense) does reveal informative membership conditions for that species, but that is all that can be hoped for. Since he realizes that Cartesians demand more of their clear and distinct ideas, Locke eventually decides it is less misleading to replace the desideratum of "clear and distinct" ideas throughout the Essay's fourth edition with the desideratum of "determinate" ideas, ideas that are consistently expressed by the same name (Epistle:13; cf. 3.11.9:513). At the same time, in a passage quoted in Sect. 3.3 above, he inserts a qualification to the effect that "specific Ideas of Substances" are subject to an additional norm of perfection (4.12.14:648). What makes one substance idea better than another, assuming both are determinate, is just that the former better supports inductive inferences, as a consequence of conforming more perfectly by correlation to the species it represents. While successful inquiry calls for further perfecting the idea to make it more adequately represent that species, Locke would see no point in aiming to formulate a new complex idea that remains an idea of the same species in the propositional sense. 42

\section{A lesson for current debates?}

What if, together with many philosophers of an "externalist" bent, we reject both Cartesian rationalism and Lockean rationalism? ${ }^{43}$ I think we can still draw the following lesson from the way Descartes and Locke bifurcate intentionality. Their shared insight is this: the purposes for which we seek an answer to question (1) differ so significantly from the purposes for which we seek an answer to question (2) that we have little reason to expect any neat connection between the kinds of intentionality each answer will invoke. This insight carries consequences for two broad approaches to mental and linguistic intentionality, one "anti-representationalist" and the other "representationalist."

\footnotetext{
41 See the previous note.

${ }^{42}$ In conceding that Locke could even make sense of distinct complex ideas that share an object in the propositional sense, I am imagining that he would allow a qualification to (a) of Sect. 3.2. Consider the rare case in which distinct substance ideas mutually agree with respect to "necessary connexion," whence the same objects must conform to each idea. In such a case, I presume, he would count both ideas as being of the same species in the propositional sense.

${ }^{43}$ For a defense of sophisticated versions of both Lockean and Cartesian rationalism, based on an entirely different bifurcation of content, see Chalmers 2012.
} 
On the one hand, I have in mind Robert Brandom's anti-representationalism concerning what I have called propositional intentionality, which corresponds to what he calls "discursive intentionality." ${ }^{4}$ Even if Lockean rationalism is misguided on externalist grounds, Locke is surely right to stress the connection between our ascriptions of propositional attitudes and of truth or falsity and our interest in clarifying and resolving apparent disagreements. A sophisticated elaboration of this theme can be found in Brandom's view of our propositional intentional vocabulary as serving to make explicit what is implicit in our practice of challenging or deferring to one another's assertions. ${ }^{45}$ Though Brandom doesn't explicitly motivate his antirepresentationalism this way, one might argue that once we appreciate this distinctive function of propositional intentional vocabulary, we will no longer be tempted by "representationalist" explanations what it is to speak or think that thus-and-so, and hence to speak or think "of something" in the propositional sense. In response to this motivation for anti-representationalism about Brandomian discursive intentionality, however, a representationalist could concede the point, but insist that she is pursuing question (2), not question (1). That is to say, she doesn't intend her accounts of mental or linguistic representation to serve in explanations of what it consists in to think or speak "of something" in the propositional sense. Furthermore, she can argue that theorists who concentrate exclusively on propositional ofness risk neglecting an important, and perhaps largely autonomous, dimension of the bearing of thought and language on the world. 46

On the other hand, there may also be a lesson for those representationalist theorists whose goal, as articulated by Ruth Millikan, is to "explain the mechanisms, including the contributions of supporting environmental structures, that together account for cases of proper cognitive functioning." 47 One such approach posits mechanisms which, on the occasions they have earned their keep by contributing to successful cognitive functioning, have done so by exploiting systematically specifiable correlations between mental or linguistic structures and objects, properties, or states of affairs. This is the broad approach taken by Millikan herself and by

\footnotetext{
${ }^{44}$ See e.g. Brandom 2008, ch. 6.

${ }^{45}$ See especially Brandom 1994, ch. 8.

${ }^{46}$ Brandom has recently expressed openness to notions of "representation" that are distinct from the "discursive representational" notions that fall directly out of propositional intentionality (2011, 209-19). However, he doesn't raise the question whether the same conceptually contentful item might "represent" distinct objects in the discursive and non-discursive senses.

47 Millikan 1993, 363.
} 
Boyd. ${ }^{48}$ Here I would like to call attention to an assumption that is invariably made by such theorists. They assume that the representational notions they employ, in addressing question (2), can simultaneously be used to explain those semantic properties that we ordinarily attribute in virtue of our use of the propositional notions used in question (1). Such properties include reference and truth conditions as ordinarily understood: if a mental or linguistic item expresses the proposition that water is liquid, it follows immediately that it has the truth condition that water is liquid, and that it involves constituents that refer or apply to water and to liquid things. The unargued assumption that the representationalist's intentional notions can be used to explain reference and truth conditions may place an unwarranted restriction on the theories of representation at issue.

Understanding how Descartes and Locke are driven to bifurcate intentionality can thus help bring into focus questions that diverse present-day approaches to intentionality have yet to sufficiently address. 49

\section{References}

Adam, Charles and Paul Tannery, eds. 1964-76. Oeuvres de Descartes. Paris: J. Vrin.

Alanen, Lilli. 2003. Descartes's Concept of Mind. Cambridge, Mass.: Harvard University Press.

Anstey, Peter. 2011. Locke and Natural Philosophy. Oxford: Oxford University Press.

Atherton, Margaret. 2007. "Locke on Essences and Classification.” In Newman 2007.

Ayers, Michael. 1991. Locke: Epistemology and Ontology. London: Routledge.

Ayers, Michael. 1998. Ideas and Objective Being. In The Cambridge History of Seventeenth-

Century Philosophy, ed. D. Garber and M. Ayers. Cambridge: Cambridge University Press.

Boyd, Richard. 1991. Realism, Anti-Foundationalism and the Enthusiasm for Natural Kinds.

Philosophical Studies 61: 127-48.

Boyd, Richard. 1999. Kinds as the 'Workmanship of Men': Realism, Constructivism, and Natural Kinds. In Rationalität, Realismus, Revision, ed. J. Nida-Rümelin. Berlin: De Gruyter.

\footnotetext{
${ }^{48}$ See also Mark Wilson's case studies in the history of science $(2006,2000)$. Wilson advocates "the 'correlational point of view': we objectively study how an unfolding reasoning process manages to arrange itself with respect to an independent reality.... This supplies a primitive notion of "truth condition" that is entirely erected upon the correspondences uncovered..." (2000, 384).

${ }^{49}$ Earlier versions of this paper were presented at the Australian National University and the University of New South Wales. For helpful discussion, I would like to thank those audiences as well as the organizers and participants of the Berlin workshop that resulted in this volume, especially Martin Lenz, Antonia LoLordo, Dominik Perler and Anik Waldow. I dedicate the paper to the memory of Joseph L. Camp, Jr., who first made me want to learn from Early Modern theories of intentionality.
} 
Boyd, Richard. 2010. Realism, Natural Kinds, and Philosophical Methods. In The Semantics and Metaphysics of Natural Kinds, ed. H. Beebee and N. Sabbarton-Leary. New York: Routledge. Brandom, Robert. 1994. Making It Explicit: Reasoning, Representing and Discursive Commitment. Cambridge, Mass.: Harvard University Press.

Brandom, Robert. 2008. Between Saying and Doing: Towards an Analytic Pragmatism. Oxford: Oxford University Press.

Brandom, Robert. 2011. Pragmatism, Expressivism, and Anti-Representationalism: Local and Global Possibilities. In his Perspectives on Pragmatism: Classical, Recent and Contemporary. Cambridge, Mass.: Harvard University Press.

Brown, Deborah. 2007. Objective Being in Descartes: That Which We Know or That By Which We Know. In Representation and Objects of Thought in Medieval Philosophy, ed. H. Lagerlund. Aldershot: Ashgate.

Carriero, John. 2009. Between Two Worlds: A Reading of Descartes's Meditations. Princeton: Princeton University Press.

Chalmers, David. 2012. Constructing the World. Oxford: Oxford University Press.

Clemenson, David. 2007. Descartes's Theory of Ideas. London: Continuum.

Conn, Christopher Hughes. 2002. Locke on Natural Kinds and Essential Properties. Journal of Philosophical Research 27: 475-97.

Cottingham, John, Robert Stoothoff, Dugald Murdoch, and Anthony Kenny, trans. 1984-91. The Philosophical Writings of Descartes. Cambridge: Cambridge University Press.

De Rosa, Raffaella. 2010. Descartes and the Puzzle of Sensory Representation. Oxford: Oxford University Press.

Doyle, John, trans. 2001. The Conimbricenses: Some Questions on Signs (includes translation of Book 1, chapter 1 of the Coimbran Dialectic of 1607). Milwaukee: Marquette University Press.

Fodor, Jerry. 1998. Concepts: Where Cognitive Science Went Wrong. Oxford.

Grüne, Stefanie. René Descartes. In Perler and Haag 2010, vol. 2.

Hoffman, Paul. 1996. Descartes on Misrepresentation. Journal of the History of Philosophy 34: $357-81$.

Hoffman, Paul. 2002. Direct Realism, Intentionality, and the Objective Being of Ideas. Pacific Philosophical Quarterly 83: 163-79. 
Kornblith, Hilary. 1993. Inductive Inference and its Natural Ground: An Essay in Naturalistic Epistemology. Cambridge, Mass.: MIT Press.

Lennon, Thomas. 2007. Locke on Ideas and Representation. In Newman 2007.

Lenz, Martin. 2010a. John Locke. In Perler and Haag 2010, vol. 2.

Lenz, Martin. 2010b. Locke’s Sprachkonzeption. Berlin: De Gruyter.

Locke, John. 1689. An Essay Concerning Human Understanding, ed. P. Nidditch. Oxford: Oxford University Press, 1975.

Mattern, Ruth. 1986. Locke on Natural Kinds as the 'Workmanship of the Understanding'. Locke Newsletter 17: 45-92.

Millikan, Ruth. 1993. White Queen Psychology; or, the Last Myth of the Given. In her White Queen Psychology and Other Essays for Alice. Cambridge, Mass.: MIT Press.

Millikan, Ruth. 2000. On Clear and Confused Ideas: An Essay About Substance Concepts. Cambridge: Cambridge University Press.

Mori, Gianluca. 2012. Hobbes, Descartes, and Ideas: A Secret Debate. Journal of the History of Philosophy 50: 197-212.

Naaman-Zauderer, Noa. 2010. Descartes' Deontological Turn: Reason, Will, and Virtue in the Later Writings. Cambridge: Cambridge University Press.

Nelson, Alan. 1996. The Falsity in Sensory Ideas: Descartes and Arnauld. In Interpreting Arnauld, ed. E. Kremer. Toronto: University of Toronto Press.

Newman, Lex, ed. 2007. The Cambridge Companion to Locke's 'Essay Concerning Human Understanding'. Cambridge: Cambridge University Press.

Nuchelmans, Gabriel. 1983. Judgment and Proposition: From Descartes to Kant. Amsterdam: North-Holland.

Ott, Walter. 2012. What is Locke's Theory of Representation? British Journal for the History of Philosophy 20: 1077-1095.

Pasnau, Robert. 1997. Theories of Cognition in the Later Middle Ages. Cambridge: Cambridge University Press.

Pasnau, Robert. 2011. Metaphysical Themes: 1274-1671. Oxford: Oxford University Press.

Perler, Dominik. 1996. Repräsentation bei Descartes. Frankfurt: Vittorio Klostermann.

Perler, Dominik. Einleitung. In Perler and Haag 2010, vol. 1.

Perler, Dominik and Johannes Haag, eds. 2010. Ideen: Repräsentationalismus in der frühen Neuzeit, 2 vols. Berlin: De Gruyter. 
Prinz, Jesse. 2000. The Duality of Content. Philosophical Studies 100: 1-34.

Shapiro, Lionel. 1999. Toward 'Perfect Collections of Properties': Locke on the Constitution of Substantial Sorts. Canadian Journal of Philosophy 29: 551-593.

Shapiro, Lionel. 2010. Two Kinds of Intentionality in Locke. Pacific Philosophical Quarterly 91:554-86.

Shapiro, Lionel. 2012. Objective Being and 'Ofness' in Descartes. Philosophy and Phenomenological Research. 84: 378-418.

Simmons, Alison. Forthcoming. Representation. In The Cambridge Descartes Lexicon, ed. L. Nolan. Cambridge: Cambridge University Press.

Stuart, Matthew. 1999. Locke on Natural Kinds. History of Philosophy Quarterly 16: 277-97.

Suárez, Francisco. Disputationes metaphysicae. 1597. In Disputaciones metafísicas, ed. and trans. S. Rábade Romeo, S. Caballero Sánchez and A. Puigcerver Zanón. Madrid: Gredos, 1960-6.

Wee, Cecilia. 2006. Material Falsity and Error in Descartes' Meditations. Abingdon: Routledge.

Wells, Norman. 1984. Material Falsity in Descartes, Arnauld, and Suarez. Journal of the History of Philosophy 22: 25-50.

Wells, Norman. 2003. The Conimbricenses, Descartes, Arnauld, and the Two Ideas of the Sun. The Modern Schoolman 81: 27-57.

Wilson, Margaret. 1990. Descartes on the Representationality of Sensation. Reprinted in her Ideas and Mechanism: Essays on Early Modern Philosophy, 69-83. Princeton: Princeton University Press, 1999.

Wilson, Mark. 2000. "Inference and Correlational Truth.” In Circularity, Definition and Truth, ed. A. Chapuis and A. Gupta, 371-95. New Delhi: Indian Council of Philosophical Research, 2000 .

Wilson, Mark. 2006. Wandering Significance. Oxford: Oxford University Press. 